E-JURNAL EKONOMI DAN BISNIS UNIVERSITAS UDAYANA
Available online at https://ojs.unud.ac.id/index.php/EEB/index
Vol. 10 No. 03, March 2021, pages: 109-118
e-ISSN: 2337-3067

\title{
CONSISTENCY OF PLANNING AND BUDGETING IN EDUCATION: THE CASE IN PONTIANAK CITY
}

\author{
Bayu Kharisma ${ }^{1}$ Sutyastie S. Remi ${ }^{2}$ Bugi Ario $^{3}$ Cecep Suhayli $^{4}$
}

Article history:

Submitted: 26 Desember 2020

Revised: 13 Januari 2021

Accepted:22 Januari 2021

\section{Keywords:}

Planing and Budgeting;

Human Resource;

Education;

Consistency Analysis;

\section{Kata Kunci:}

Perencanaan dan Penganggara; Sumber Daya Manusia;

Pendidikan;

Analisis Konsistensi;

\section{Koresponding:}

Departemen Of Economic, Universitas Padjadjaran, West Java, Indonesia

Email:

bayu.kharisma@unpad.ac.id ${ }^{1}$

\section{Abstract}

\begin{abstract}
Human resources are one of the key elements in national or regional development. One way to improve the quality of human resources is through education as a college means better human resources in terms of quality. Education is one of the priority programs in Pontianak City and it is clear that their government has plans to improve the quality of their human resources through education as stated in their long and medium term development plan. Therefore, this study aims to identify trends of inconsistencies between planning and budgeting in special education programs and activities in pontianak city government in 2019 by using quantitative methods through data collection. Consistency analysis is carried out by evaluating several related documents such as RPJPD 2005-2025, RPJMD 2015-2019, RKPD 2019, Renstra 2015-2019, Renja 2019, and DPA 2019. The results of the analysis showed that the planning and budgeting documents in special education programs and activities in Pontianak city were not completely consistent.
\end{abstract}

\section{Abstrak}

Sumber daya manusia merupakan salah satu elemen kunci dalam pembangunan nasional atau daerah. Salah satu cara untuk meningkatkan kualitas sumber daya manusia adalah melalui pendidikan sebagai perguruan tinggi berarti sumber daya manusia yang lebih baik dalam hal kualitas. Pendidikan merupakan salah satu program prioritas di Kota Pontianak dan jelas bahwa pemerintah mereka memiliki rencana untuk meningkatkan kualitas sumber daya manusia mereka melalui pendidikan seperti yang dinyatakan dalam rencana pembangunan jangka panjang dan menengah mereka. Oleh karena itu, penelitian ini bertujuan untuk mengidentifikasi tren inkonsistensi antara perencanaan dan penganggaran dalam program dan kegiatan khusus pendidikan di pemerintah Kota Pontianak tahun 2019 dengan menggunakan metode kuantitatif melalui pendataan. Analisis konsistensi dilakukan dengan mengevaluasi beberapa dokumen terkait seperti RPJPD 2005-2025, RPJMD 2015-2019, RKPD 2019, Renstra 20152019, Renja 2019, dan DPA 2019. Hasil analisis menunjukkan bahwa dokumen perencanaan dan penganggaran dalam program dan kegiatan khusus pendidikan di Kota Pontianak tidak sepenuhnya konsisten 


\section{INTRODUCTION}

Planing and budgeting play a very important role in achieving development goals at he region and national scales. It has been more than 20 years since a reformation happened in Indonesia (1998). It altered government system administration in which the power of planning and decision making from centralization to decentralization. Indonesia decentralization was based on Constitution No.22, 1999 which was changed by Constitution No.32, 2004 about regional government. The purpose of this decentralization is to grow welfare equally by public services and to tighten the relationship between government and local people. Regional governments have the authority to control and manage their governance issues including their finances based on Constitution No. 17 in 2003 concerning state finances and Constitution No. 33 in 2004 about the balance of state and regional finances.

The development by regional governments has to be integrated with national planning. Constitution No 25 in 2004 concerning National Development Planning System (SPPN) regulates national and regional planning. The National Development Planning System is a system of development planning procedures to deliver development plans in the long, medium, and yearly periods, implemented by state administrators and community at the central and regional levels. Regional planning refers to national planning.

Human resource is the main asset in development. Development depends on the quality of human resource. Human development can be seen in the Human Development Index (HDI). It shows the development of education, health, and economy. The growth of HDI of Pontianak city at 2010-2018 period is growing from 74.87 in 2010 to 78.56 in 2018.

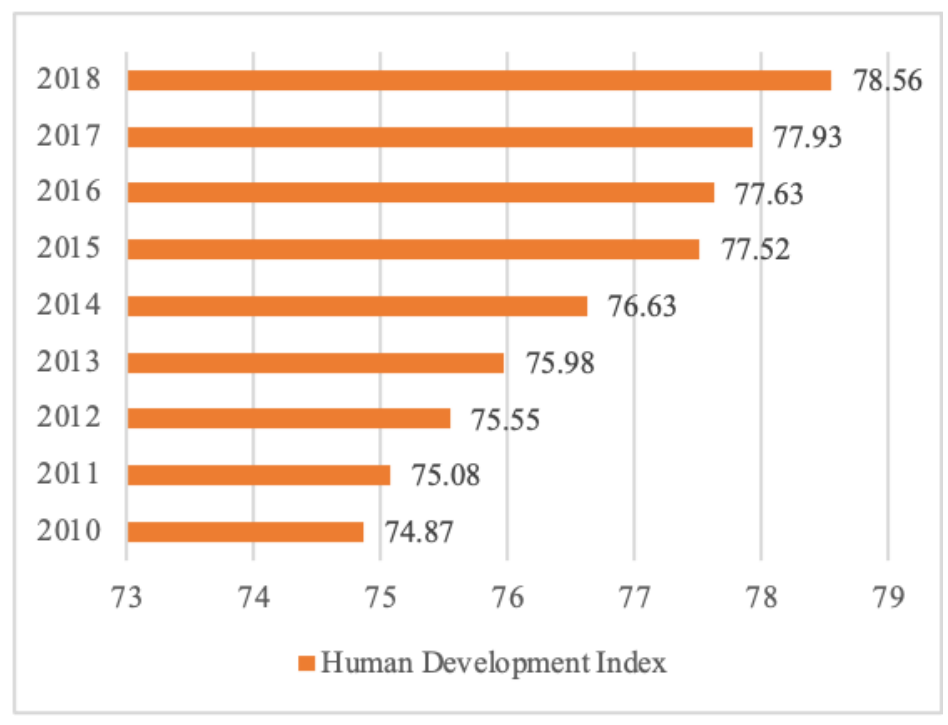

Source: Pontianak City, 2010-2018

Figure 1. HDI of Pontianak City Period 2010-2018

One way to measure the quality of human resource is through education. The higher degree of education conducts better human resource quality. Education is one of the most valuable assets in human capital. Good education brings people to have basic knowledge and skills. Human capability is the basis of the development, so people should have their freedom to develop their human capability (Sen, 2000).

In Indonesia, people have the rights and obligations of education. It is stated in The 1945 Constitution of the Republic of Indonesia that every Indonesian citizen has the rights of having education and it is an obligation to have basic education (The 1945 Constitution of The Republic of Indonesia, 1945). Education plays an important role to make Indonesia stronger and more competitive 
in the world. However, there are many several problems related to education in Indonesia: quality and access as well as the even distribution of well-trained teachers (USAID, 2013).

The regional government of Pontianak city has education plans to improve human development stated in Regional Priorities of Specified in the Twenty-year Plan (RPJPD), Regional Priorities of Specified in the Five-year Plan (RPJMD), Local Government-Wide Work Plan (RKPD), Strategic Plan (Renstra) of education, and Working Plan (Renja) of Pontianak education department. It is also stated in the regional budget (APBD or revised APBD/APBDP). The regional government of Pontianak city put on average 480 billion rupiahs in the education department in the period 20122019. It is around $17 \%$ of the regional government budget. Even though the regional budget (altered budget, APBDP) increased, the education department budget is relatively stable.

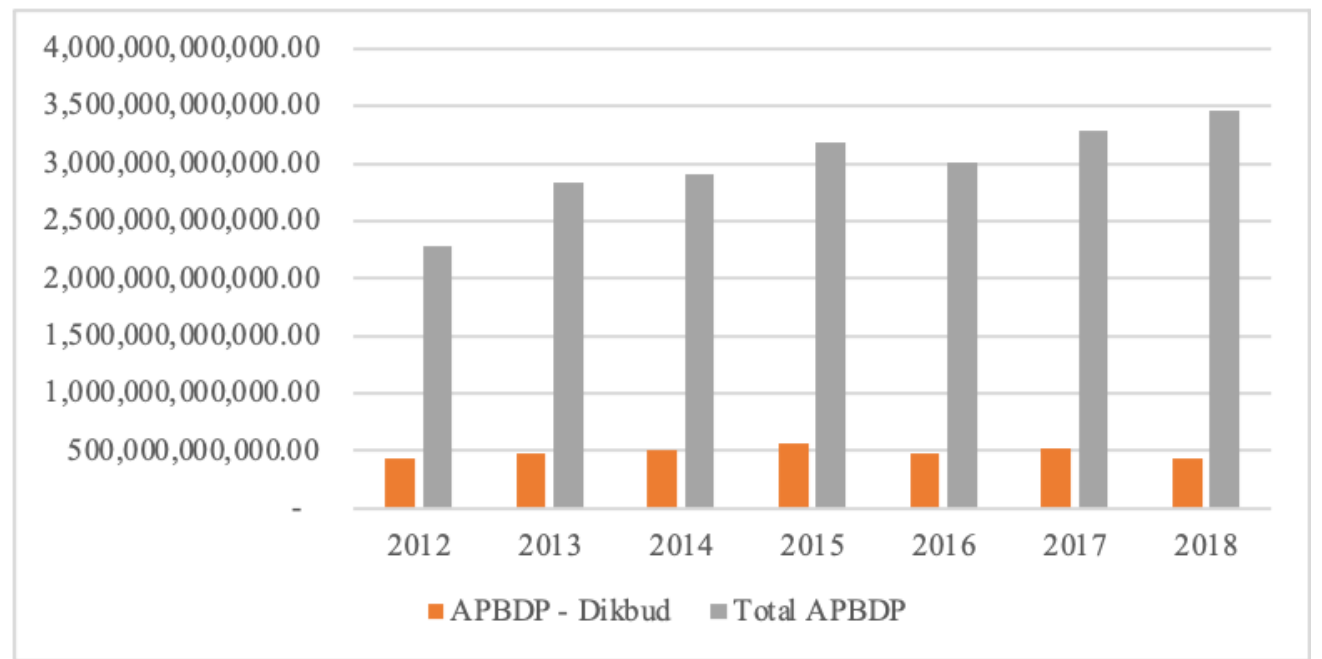

Source: RPJPD of Pontianak City, 2012-2018

Figure 2. APBDP and Education Department Budget

The regional government budget of the education department is important to improve human development through education. Thus, the education department of regional government expenditure has to be spent according to plan. The degree of correlation and consistency of the document (RKPD, KUA-PPAS, APBD) reflects the commitment of the local government and parliament to accommodate the programme priorities and aspirations of the people in local development planning (Khusaini, 2014). Failure to maintain the integration and consistency of these three documents will have an impact on the effectiveness of the achievement of the goals and objectives of regional development, public service performance and ultimately risking the credibility of local governments in carrying out the mandate of the national development priorities.

The aim of this research is to identify the consistency of planning and budgeting between RPJPD of Pontianak 2005-2025, RPJMD of Pontianak 2015-2019, RKPD of Pontianak 2019, Renstra of education of Pontianak 2019, Renja of education of Pontianak 2019, and the budget implementation documents (DPA) of education of in Pontianak APBD 2019. The contribution of this research focuses on the analysis of consistency between planning and budgeting documents in the field of education in Pontianak city that has never been studied before.

\section{RESERCH METHODS}

In this study, we used a quantitative method to determine the consistency between planning and budgeting in the education program of the regional government of Pontianak city. The consistency measurement can be done by evaluating several related documents such as RPJPD of Pontianak 2005-2015 and RPJMD of Pontianak 2015-2019, RKPD of Pontianak 2019, Renstra of education of Pontianak 2015-2019, Renja of education of Pontianak 2019, and Budget documentation (DPA) of education of Pontianak 2019. This paper analyzes the consistency level by using the 
Consolidation Matrix of Planning and Budgeting (Matriks Konsolidasi Perencanaan dan Penganggaran/MKPP) in the education sector. The consolidation matrix is created by integrating two related documents. Each part of the vision, mission, program, and activities in one document is compared with another document. Then, the consistency level is measured by percentage.

Consistency Level $(\%)=($ Consistent programs $) /($ total programs $) \times 100 \%$

Consistency level based on a percentage (Sugiyono,2003):

- Very Bad : $0.0-19.9$

- Bad : $20.0-39.9$

- Medium : $40.0-59.9$

- Good : $60.0-79.9$

- Very Good : $80.0-100.0$

\section{RESULTS AND DISCUSSION}

This paper evaluates 6 documents of planning and budgeting. They are RPJPD of Pontianak 2005-2025, RPJMD of Pontianak 2015-2019, RKPD of Pontianak 2019, Renstra of education of Pontianak 2015-2019, Renja of education of Pontianak 2019, and DPA of education of Pontianak 2019. The consolidation matrix compares two documents. This paper uses 7 (seven) consolidation matrixes to have a comparison between 6 documents, as follows:

Analysis of the consolidation matrix between RPJPD and RPJMD compares vision and mission in RPJPD and RPJMD. The vision and mission in RPJPD should reflect the development plan which is possible to be achieved by the regional government. The vision in RPJMD is not consistent with the vision in RPJPD because the vision in RPJPD is unrealistic as it wants to be the best in all aspects not only in West Kalimantan Province but also in all Kalimantan. Hence, the definition of the best in RPJPD is unmeasurable and it will be difficult to achieve. On the other hand, the vision in RPJMD is quite clear and achievable as it mentions a specific sector/area of the development. However, it is unclear that the vision in RPJMD is a part of RPJPD. Three missions in RPJMD and RPJPD are consistent with each other. However, RPJMD has 5 missions while RPJPD has 6 missions. Three missions in RPJPD are not elucidated in RPJMD, while two missions in RPJMD are not based on RPJPD. Vision and mission in RPJMD may differ from RPJPD because of the difference of elected leader.

Table 1.

Result of Consolidation Matrix between RPJMD and RKPD

\begin{tabular}{|c|c|c|c|c|}
\hline \multirow{2}{*}{ Details } & \multicolumn{2}{|c|}{ RPJMD } & \multicolumn{2}{|c|}{ RKPD } \\
\hline & Program & $\%$ & Program & $\%$ \\
\hline Consistent & & & & \\
\hline $\begin{array}{l}\text { Included in RPJMD and RKPD } \\
\text { Inconsistent }\end{array}$ & 6 & $75 \%$ & 6 & $100 \%$ \\
\hline Only in RPJMD & 2 & $25 \%$ & & \\
\hline Only in RKPD & & & 0 & $0 \%$ \\
\hline Total & 8 & $100 \%$ & 6 & $100 \%$ \\
\hline
\end{tabular}

Vision and missions in RPJMD are explained in programs that are divided into many sectors. In the education sector, RPJMD has 8 priority programs, while RKPD only has 6 programs. Of 8 priority programs in RPJMD 2015-2019, 6 programs were included in RKPD 2019 and only 2 programs were excluded. It shows that the level of consistency between RPJMD 2015-2019 and RKPD 2019 is good (75\%). Moreover, of 6 prioritize programs in RKPD 2019, all of them came from RPJMD 2015-2019. Thus, the level of consistency is very good (100\%). RKPD is structured yearly 
based on RPJMD and Renja. RKPD of Pontianak 2019 is the last scheme in RPJMD. The scenario of this RKPD is to strengthen and optimizing the development of earlier RKPD periods. Thus, the programs in RKPD may not cover all programs in RPJMD.

Table 2.

Result of Consolidation Matrix between RPJMD and Renstra

\begin{tabular}{|c|c|c|c|c|}
\hline \multirow{2}{*}{ Details } & \multicolumn{2}{|c|}{ RPJMD } & \multicolumn{2}{|c|}{ Renstra } \\
\hline & Program & $\%$ & Program & $\%$ \\
\hline Consistent & & & & \\
\hline $\begin{array}{l}\text { Both RPJMD and Renstra has the programs } \\
\text { Inconsistent }\end{array}$ & 8 & $100.00 \%$ & 8 & $47.06 \%$ \\
\hline Only in RPJMD & 0 & $0.00 \%$ & & \\
\hline $\begin{array}{l}\text { Only in Renstra } \\
\text { Total }\end{array}$ & 8 & $100.00 \%$ & $\begin{array}{c}9 \\
17\end{array}$ & $\begin{array}{r}52.94 \% \\
\mathbf{1 0 0 . 0 0 \%} \\
\end{array}$ \\
\hline
\end{tabular}

Source: RPJMD and Renstra of Pontianak City, 2010-2018

Analysis of the consolidation matrix between RPJMD and Renstra of education compares vision, mission, and programs. The vision and mission in Renstra of education may only parts of vision and mission in RPJMD because Renstra of education is specifically about education. Since Renstra of education is about education, then this paper compares programs in Renstra of education with programs of education in RPJMD. The vision "Develop intelligent with noble mind and character human" in Renstra of education is only a part of improving human resources in RPJMD. In terms of missions, RPJMD has 5 missions while Renstra of education has 6 missions. Six missions in Renstra of education are parts of two missions in RPJMD. They are correlated with mission number one "Improving the quality of human resources that are religious, intelligent, healthy, cultured and harmonious." and number two" Apply the principles of good governance in governance and implementation of the Integrity Zone through the establishment of a Corruption-Free Area in the public service sector." RPJMD has 8 education programs, while Renstra of education has 17 programs. All programs in RPJMD are elucidated in Renstra of education. Thus, 8 programs are consistent between RPJMD and Renstra of education. However, of 17 programs of education in Renstra 2015-2019, 9 additional programs were not from RPJMD. It means the level of consistency is quite consistent. The reason for this is because Renstra of education focuses on education, while RPJMD is general plan in 5-year-period. So, the additional programs might be come from the citizens aspiration based on the Pontianak specified needs.

Table 3.

Result of Consolidation Matrix between Renstra and Renja

\begin{tabular}{|c|c|c|c|c|c|c|c|c|}
\hline \multirow{2}{*}{ Details } & \multicolumn{4}{|c|}{ Program } & \multicolumn{4}{|c|}{ Activities } \\
\hline & Renstra & $\%$ & Renja & $\%$ & Renstra & $\%$ & Renja & $\%$ \\
\hline \multicolumn{9}{|l|}{ Consistent } \\
\hline $\begin{array}{l}\text { Included in Renstra } \\
\text { and Renja }\end{array}$ & 10 & 58.82 & 10 & 76.92 & 55 & 50.93 & 52 & 52.53 \\
\hline \multicolumn{9}{|l|}{ Inconsistent } \\
\hline Only in Renstra & 7 & 41.18 & & & 53 & 49.07 & & \\
\hline Only in Renja & & & 3 & 23.08 & & & 47 & 47.47 \\
\hline Total & 17 & 100.00 & 13 & 100.0 & 108 & 100.00 & 99 & 100.00 \\
\hline
\end{tabular}

Source: Renja and Renstra of Pontianak City, 2010-2018

This section compares programs and activities between Renstra of education and Renja of the education department. Table 3 shows that the consistency of programs and activities is in the medium level of consistency. The number of programs and activities in Renstra and Renja is different. Renstra has 17 programs and 108 activities, while Renja has 13 programs and 99 activities. In terms of 
programs, Renstra of education has 4 programs more than Renja. Ten programs in Renstra are stated in Renja and seven programs are not in Renja. Thus, the consistency of Renstra programs stated in Renja is around 58.82\%. Renja has fewer programs than Renstra, but 10 of 13 programs of Renja are stated in Renstra. Three programs of Renja unstated in Renstra are "Cultural Richness Management Program", "Cultural Diversity Program", and "Cooperation Development of Cultural Richness Management Program".

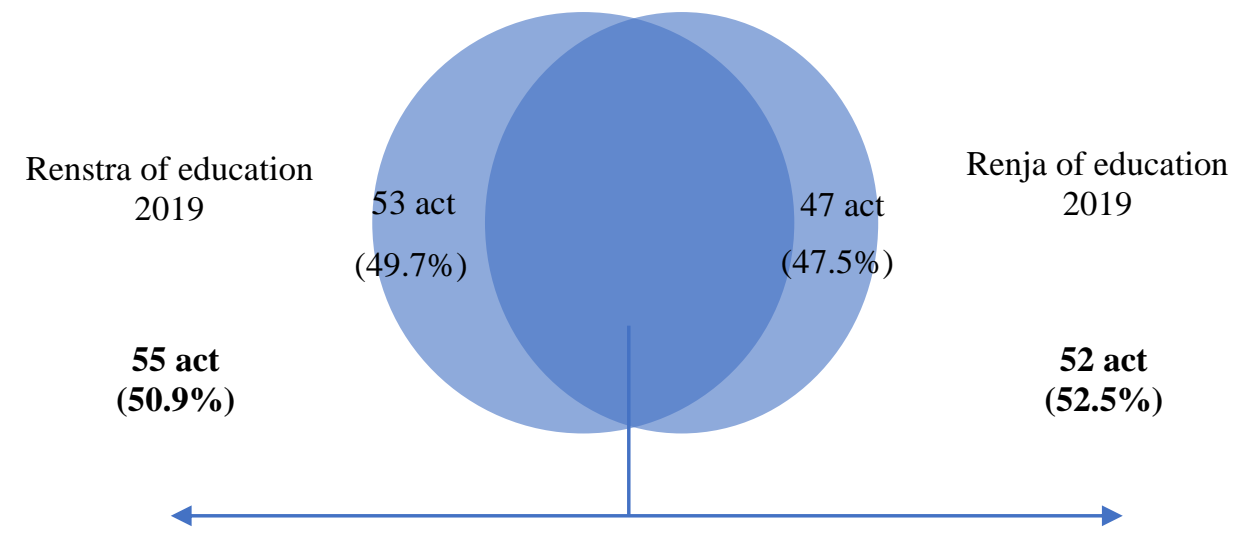

Figure 3. Interrelationship Diagram between activities in Renstra of Education and Renja of Education Department

In terms of activities, Renstra of education has 9 more activities more than Renja. Around $50 \%$ of total activities in Renstra or 53 activities of 108 activities are not elucidated in Renja and around $47 \%$ of total Renja activities or 47 activities of 99 activities are not stated in Renstra. The number of activities that consistency stated in both Renstra and Renja is different because activity in Renstra can be divided into more than one activity in Renja and vice versa. Renstra has 8 programs that are included in 3 programs of Renja, while Renja has 4 programs that are included in 2 programs of Renstra. Besides that, many activities under Renstra's program are stated as similar activities in different Renja programs and vice versa. The probability of the differences between both documents are low commitment between stakeholders and policy makers, low quality of planning and budgeting officials, special fund from central government for different programs and activities, and lack of attention from city mayor for the process of planning and budgeting (Fitry, 2012).

Table 4.

Result of Consolidation Matrix between Renja of education 2019 and RKPD of education 2019

\begin{tabular}{|c|c|c|c|c|c|c|c|c|}
\hline \multirow[b]{2}{*}{ Details } & \multicolumn{4}{|c|}{ Program } & \multicolumn{4}{|c|}{ Activities } \\
\hline & Renja & $\%$ & $\begin{array}{c}\text { RKP } \\
\text { D } \\
\end{array}$ & $\%$ & $\begin{array}{c}\text { Renj } \\
\mathbf{a} \\
\end{array}$ & $\%$ & RKPD & $\%$ \\
\hline \multicolumn{9}{|l|}{ Consistent } \\
\hline Included in Renja and RKPD & 10 & $76.9 \%$ & 10 & $100 \%$ & 82 & $83 \%$ & 82 & $91 \%$ \\
\hline \multicolumn{9}{|l|}{ Inconsistent } \\
\hline Only in Renja & 3 & $23.1 \%$ & & & 17 & $17 \%$ & & \\
\hline Only in RKPD & & & 0 & $0 \%$ & & & 8 & $9 \%$ \\
\hline Total & 13 & $100 \%$ & 10 & $100 \%$ & 99 & $100 \%$ & 90 & $100 \%$ \\
\hline
\end{tabular}

Source: Renja and RKPD of Pontianak City, 2010-2018

The Renja of education of Pontianak 2019 has 13 programs and 99 activities, while the RKPD of education of Pontianak 2019 has 10 programs and 90 activities. From the table 4, it can be seen that the planning and the drafting of educational programs and activities in 2019 were not fully consistent as some programs and activities in Renja of education of Pontianak 2019 were not included in RKPD of education 2019. From the 13 programs in Renja of education 2019, 10 programs were 
accommodated in RKPD of education 2019, meaning that the level of consistency is consistent (76.9\%), while the remaining 3 programs (23.1\%) were not included in RKPD of education 2019. It is because those 3 programs were cultural specified programs that were not related with education. On the other hand, of 10 programs in RKPD of education 2019, all of them were coming from Renja of education 2019. It means the level of consistency is very good (100\%).

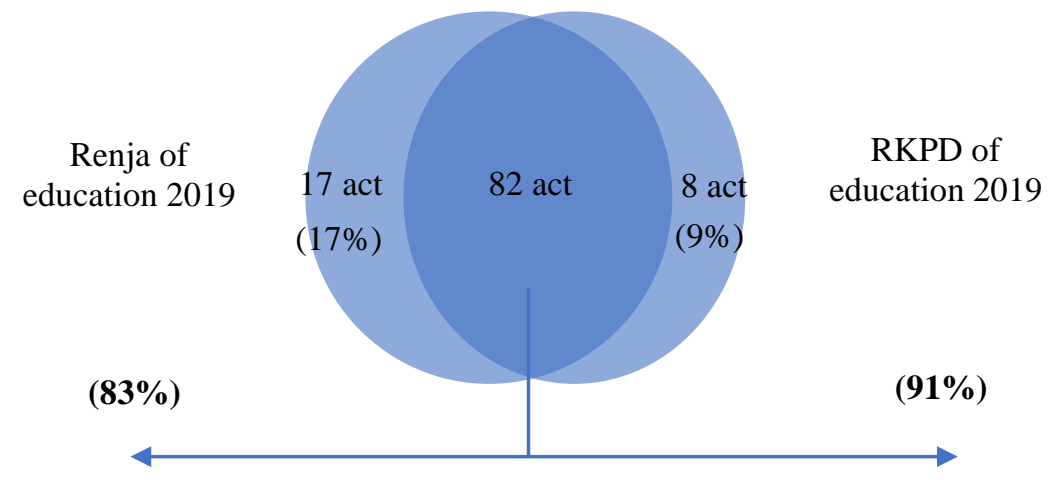

Figure 4. Interrelationship diagram between Renja of Education 2019 and RKPD of Education 2019

Consistency analysis of educational activities in Renja of education and RKPD of education shows that of the 99 educational activities in Renja of education, 82 activities were accommodated in the RKPD of education, meaning that they showed a very good level of consistency (83\%), while the remaining 17 activities (17\%) were excluded in RKPD of education. It is because those activities were not focused on educational development. On the other hand, of the 90 educational activities in RKPD of education, only 8 activities that were not following the Renja of education 2019 , meaning the level of consistency is very consistent $(91 \%)$. Those 8 additional activities were included in RKPD of education 2019 due to urgency reason to improve the operational of education services as most activities were about rehabilitation of school building in Pontianak.

Table 5.

Result of Consolidation Matrix between RKPD of education 2019 and DPA of education 2019

\begin{tabular}{lcccccccc}
\hline \multicolumn{1}{c}{ Details } & \multicolumn{4}{c}{ Program } & \multicolumn{3}{c}{ Activities } \\
\cline { 2 - 8 } & RKPD & \% & DPA & \% & RKPD & \% & DPA & $\%$ \\
\hline $\begin{array}{l}\text { Consistent } \\
\text { Included in RKPD and }\end{array}$ & 10 & $100 \%$ & 10 & $76.9 \%$ & 82 & $91 \%$ & 82 & $83 \%$ \\
$\begin{array}{l}\text { DPA } \\
\text { Inconsistent }\end{array}$ & & & & & & & & \\
Only in RKPD & 0 & $0 \%$ & & & 8 & $9 \%$ & & $17 \%$ \\
$\begin{array}{l}\text { Only in DPA } \\
\text { Total }\end{array}$ & 10 & $100 \%$ & 13 & $100 \%$ & 90 & $100 \%$ & 99 & $100 \%$ \\
\hline
\end{tabular}

Source: RKPD and DIPA of Pontianak City, 2010-2018

The RKPD of education of Pontianak 2019 has 10 programs and 90 activities, while the DPA of education of Pontianak 2019 has 13 programs and 99 activities. According to the table, of the 10 programs in RKPD of education 2019, all of them were accommodated in DPA of education 2019, meaning that the level of consistency is very consistent (100\%). On the other hand, of 13 programs in DPA of education 2019, 3 additional activities were not following the RKPD of education 2019. However, the level of consistency is still at a good level (76.9\%). From this analysis, it is clear that the drafting of DPA of education was not fully following the RKPD. Instead, the structure of DPA was similar to Renja of education. 


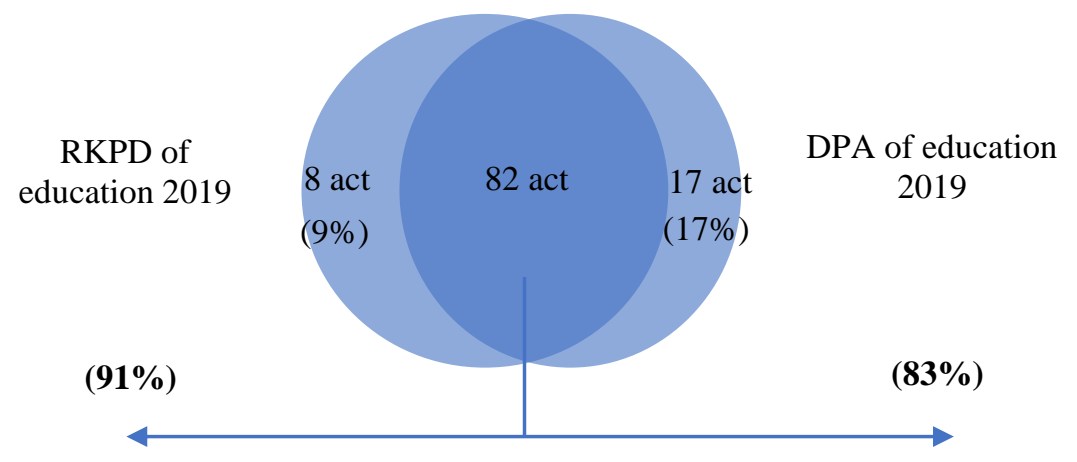

Figure 5. Result of Consolidation Matrix between RKPD of education 2019 and DPA of education 2019

On the other hand, consistency analysis of educational activities in RKPD of education and DPA of education shows that of the 90 educational activities in RKPD of education 82 activities were accommodated in the DPA of education, meaning that they showed a very good level of consistency (91\%), while the remaining 8 activities $(9 \%)$ were excluded in DPA of education. Meanwhile, of the 99 educational activities in DPA of education, 17 activities were not following the RKPD of education 2019 , meaning the level of consistency is good (83\%). Similar to consistency analysis in educational programs, it is obvious that the mismatch activities between RKPD of education and DPA of education happened because instead of using the RKPD of education 2019 as a guideline, DPA of education 2019 adopted the Renja of education 2019 in their proposal. Its shows that the coordination between the executives and the educational department is not solid.

Education is one of Pontianak city's priorities in their development program. It can be seen in RPJMD of Pontianak city 2015-2019, where their government set a mission to improve the quality of Pontianak's human resources that are religious, intelligent, healthy, cultured, and harmonious as their number 1 mission in their five-years regime. So, to measure the consistency level between DPA of education 2019 and RPJMD of Pontianak city 2015-2019 we look at the relevancies between educational activities in DPA of education 2019 with mission number 1 in RPJMD of Pontianak city 2015-2019.

Table 6.

Result of Consolidation Matrix between DPA of education 2019 and Pontianak's Mission in RPJMD 20152019

\begin{tabular}{lcc}
\hline \multicolumn{1}{c}{ Details } & \multicolumn{2}{c}{ DPA - RPJMD } \\
\cline { 2 - 3 } & Activities & $\mathbf{7 0}$ \\
\hline Consistent & $\mathbf{7 4}$ & $\mathbf{7 5 \%}$ \\
Relevant with RPJMD & $\mathbf{2 5}$ & $\mathbf{2 5 \%}$ \\
Inconsistent & & $100 \%$ \\
Irrelevant with RPJMD & 99 & \\
\hline
\end{tabular}

Source: DPA and RPJMD of Pontianak City, 2010-2018

From the Table 6, of 99 educational activities in DPA of education 2019, 74 activities were relevant to the Pontianak city's government mission to improve their human resources qualities and 25 activities were not relevant to the mission. The result of the analysis shows that $75 \%$ of educational activities in DPA of education 2019 were relevant with RPJMD and it has a good level of consistency. While the remaining $25 \%$ activities were not relevant as those activities will not improve the quality of human resources of Pontianak city. 


\section{CONCLUSION AND RECOMMENDATION}

Overall, the consistency analysis of planning and budgeting documents of education in Pontianak city showed varying degrees of consistency, from medium level of consistency to very consistent level. Since the improvement in human resources qualities is one of the main objectives in Pontianak city's development, the necessary programs and activities should be planned and implemented consistently by the Pontianak's government to achieve the expected result.

According to the evaluation of consistency levels among planning and budgeting documents of Pontianak's educational development, some actions can be taken by Pontianak's government to enhance the quality of their educational sector and human resources. First, inconsistency level occurred in several documents shows that the intergovernmental coordination in Pontianak is weak. To overcome this problem, the Mayor of Pontianak should pay more attention to the educational specified programs and activities by monitoring the process since the early stage. Moreover, the Mayor can improve the coordination between the executives and the educational department by ordering two parties to meet frequently to discuss and to share their agenda in educational sector. Second, to improve the quality of Pontianak's human resources, the government of Pontianak should concern more to their officials' qualities too to support the government in preparing and executing the programs and activities related to educational development. It can be achieved by continuously provide related courses in planning and budgeting process to maintain their level of knowledge. Last, consider the existence of special monitoring team such as quality assurance in charge of monitoring and evaluating the performance of the unit related to achievement of government target. These would ensure their objective in improving both educational sector and human resources quality can be achieved according to the plan.

\section{REFERENSI}

Amryyanti, R., Sukaatmadja, G., \& Nurcahya, I. (2013). Pengaruh Kualitas Layanan, Produk, \& Kewajaran Harga Terhadap Kepuasan \& Loyalitas Pelanggan Pada LnC Skin Care Singaraja. E-Jurnal Ekonomi \& Bisnis, 2(1),22-29

Berke, P. R., \& French, S. P. (1994). The Influence of State Planning Mandates on Local Plan Quality. Journal of Planning Education and Research, 13(4), 237-250. https://doi.org/10.1177/0739456X9401300401

Binns, T., \& Nel, E. (2002). Devolving Development: Integrated Development Planning and Developmental Local Government in Post-apartheid South Africa. Regional Studies, 36(8), 921-932. https://doi.org/10.1080/0034340022000012342

Denhardt, R. B. (1985). Strategic Planning in State and Local Government. State \& Local Government Review, 17(1), 174-179.

Deyle, R. E., \& Smith, R. A. (1998). Local government compliance with state planning mandates: The effects of state implementation in florida. Journal of the American Planning Association, 64(4), 457-469. https://doi.org/10.1080/01944369808976004

Fitry, R. (2012). Analisis Konsistensi Perencanaan dan Penganggaran Bidang Kesehatan Kota Lubuklinggau Tahun 2010.

Khusaini, M. (2014). Local government planning and budgeting process: A case of districts and cities in Indonesia. International Journal of Economic Policy in Emerging Economies. 54(1), 1-20 https://doi.org/10.1504/IJEPEE.2014.063190

Managing Public Expenditure. (2003). 93-130. https://doi.org/10.1787/eco_surveys-gbr-2002-6-en

Makmur, Purnomo, E., \& Yulfita 'Aini. (2017). Pengaruh Harga, Kualitas Produk \& Lokasi terhadap inat Beli Konsumen dalam Membeli Beras Lokal (Studi Kasus Desa Rambah Utama). Jurnal Mahasiswa Prodi Manajemen UPP, 4(1), 23-45.

Martín-Consuegra, D., Molina, A. \& Esteban, Á. (2007), "An integrated model of price, satisfaction and loyalty: an empirical analysis in the service sector", Journal of Product \& Brand Management, 16(7), 459-468.

Martínez, P. \& Rodríguez, I. (2013). International Journal of Hospitality Management CSR and customer loyalty: The roles of trust, customer identification with the company and satisfaction', International Journal of Hospitality Management. 35(2), 89-99. 
Martínez, P., Pérez, A. \& Del Bosque, I.R. (2014), "CSR Influence On Hotel Brand Image And Loyalty", Academia Revista Latinoamericana De Administración, 27(2), 267-283.

Murtiasih, S., Sucherly, S., \& Siringoringo, H. (2014). Impact Of Country Of Origin And Word Of Mouth On Brand Equity. Marketing Intelligence \& Planning. 32(5), 616-629.

Nurhayati, Risky. (2011). Pengaruh Kualitas Produk \& Harga terhadap Kepuasan Pelanggan, Skripsi. Administrasi Bisnis Fakultas Ilmu Sosial \& Politik Universitas Veteran Yogyakarta.

Panjaitan, Inggrid. (2016). Pengaruh Pelayanan \& Harga Pada Go-Jek Terhadapkepuasan Konsumen Dengan Minat Sebagai Variabel Moderating. Media Studi Ekonomi, 19(2), 45-60.

Prasada, I. P. E. A., \& Ekawati, N. W. (2018). Peran Kepuasan Pelanggan Memediasi Pengaruh Persepsi Harga Terhadap Loyalitas Pelanggan. E-Jurnal Manajemen Universitas Udayana, 7(10), 5284.

Purwoadi, Rifqi. (2013). Pengaruh Kualitas Produk \& Kewajaran Harga Terhadap Loyalitas dengan Kepuasan Konsumen Sebagai Variabel Intervening. Management Analisys Journal, 2 (1). 10-20.

Poister, T. H., \& Streib, G. (2005). Elements of strategic planning and management in municipal government: Status after two decades. Public Administration Review, 65(1), 45-56.

https://doi.org/10.1111/j.1540-6210.2005.00429.x 